\title{
Výuka o vědě a jejích dějinách: Cesko versus Západ ${ }^{1}$
}

\author{
Jana Poupová \\ Univerzita Karlova, Př́rodovědecká fakulta, katedra učitelství a didaktiky biologie
}

\begin{abstract}
Abstrakt: Studie se zaměřuje na problematiku výuky o vědě a jejích dějinách. Vychází $z$ instrumentálního pojetí dějin vědy, $t j$. $v$ historii spatřuje nástroj umožňující přiblížit žákủm stěžejní poučení o vědě. Stat' upozorňuje, že porozumění vědeckému pohledu na svět (jeho prínosu i limitům) je významným cílem výuky přírodovědných předmětů a že řada zemí doporučuje využívat dějiny vědy v rámci tzv. výuky př́rodních věd v souvislostech. Studie popisuje, jaké požadavky na výuku o vědě uvádějí Rámcový vzdělávací program pro základní vzdělávání (RVP ZV) a Rámcový vzdělávací program pro gymnázia (RVP G), a všímá si, zda je pro jejich naplnění doporučována výuka dějin vědy. Zjištěný stav je diskutován v porovnání se situací ve vybraných anglofonních zemích (jmenovitě Velké Británii, USA a Kanadě), kterou zachytily materiály Mezinárodního sdružení pro výuku dějin, filozofie a vědy (IHPST) a dokumenty EU. Ze studie vyplývá, že se česká výuka o vědě orientuje především na osvojení obvyklého postupu přírodovědného bádání. Vztahu vědy a společnosti je věnováno poměrně málo pozornosti, zamyšlení nad povahou vědeckého poznání se od našich žáků nepožaduje vůbec. K zlepšení této situace doporučuje autorka začít ve výuce využívat dějiny vědy. Toto opatření by si vyžádalo zohlednit dějiny věd nejen v kurikulárních dokumentech, ale také v učebnicích a při vzdělávání učitelů.
\end{abstract}

Klíčová slova: výuka o vědě, povaha vědy, dějiny vědy, rámcový vzdělávací program

\section{Learning About Science and its History: Czech Republic vs. the West}

Abstract: This study deals with learning about science and its history. It is based on an instrumental conception of the history of science; i. e. history of science is believed to be very instructive as far as the nature of science is concerned. To give pupils insight into the benefits as well as the limits of the scientific way of thinking is considered to be a very important goal of science education. In order to achieve this goal many countries recommend teaching the history of science as a part of the so-called STS education. This article describes how Czech curriculum refers to this issue at both the primary and secondary school levels. The Czech situation is discussed in comparison to that of several English-speaking countries (Great Britain, USA and Canada). Documents of the International History, Philosophy and Science Teaching Group and of the European Union were used for this purpose. The study shows that Czech education deals especially with scientific methodology and does not pay enough attention to interactions between science and society nor to the nature of scientific knowledge. Teaching history of science is recommended to improve this. It is necessary to embody the history of science not only into curriculum documents, but also into textbooks and teachers' educational programmes.

Keywords: learning about science, nature of science, history of science, framework educational programme

Tato publikace byla podpořena programem Univerzitní výzkumná centra UK (UNCE/HUM/024). 
2 V mnoha zemích Evropy se v kurikulárních dokumentech setkáváme s pojmem přírodovědná gramotnost (Maršák et al., 2011). Přírodovědná gramotnost obnáší aktivní osvojení pojmového aparátu používaného k popisu studovaných jevů, ovládnutí metod př́rodovědného bádání a získání povědomí o propojenosti metodologie s etikou vědecké práce a o interakci prírodních věd a ostatních lidských aktivit (Faltýn, Nemčíková, \& Zelendová, 2010). Jedno z nejrozsáhlejších mezinárodních šetření zaměřených (nejen) na prírodovědnou gramotnost PISA (Programme for International Student Assessment) pokládá za přírodovědně gramotného člověka, který je „schopen přemýšlet a jednat ve všech věcech souvisejících s přírodními vědami a jejich principy a je schopen a ochoten zapojit se do věcné debaty o př́rodních vědách a technologiích“ (Blažek, 2017, s. 7). Mezi stěžejní dovednosti, které by měl př́rodovědně gramotný jedinec ovládat, PISA počíá: vysvětlovat jevy vědecky, vyhodnocovat a navrhovat prírodovědný výzkum a vědecky interpretovat data a důkazy. Osvojení těchto dovedností závisí na žákových znalostech obsahového, procedurálního a epistemického rázu. Zatímco procedurální znalost zahrnuje obvyklé postupy vědeckého bádání, epistemická se týká posouzení výsledků vědeckého výzkumu, vhodnosti postupu či podloženosti závěrů, tj. vyžaduje adekvátní pochopení role teorie, hypotézy a pozorování (tamtéž, s. 7-8).

Z uvedeného vyplývá, že pro rozvoj přírodovědné gramotnosti žáků je zapotřebí věnovat ve škole pozornost nejenom obsahu jednotlivých vědeckých oborů, ale také obecnějším principům fungování vědy. Pro učivo, které ukazuje povahu vědecké práce $v$ širších souvislostech, se $v$ anglicky psané literatuře uživá výraz Nature of Science (NOS). Výuka o povaze vědy obvykle spočívá v propojení historického, filozofického a sociologického pohledu na vědecké bádání (McComas, 2014). Pro takto zaměřenou výuku budeme dále $v$ textu používat sousloví výuka $o$ vědě.

Navzdory široce pojímané prírodovědné gramotnosti se $k$ výuce prírodních věd dlouho přistupovalo tak, jako by jejím hlavním cílem bylo předat žákům vybraný soubor vědomostí určený k zapamatování (DeBoer, 2014). Požadavek, aby se žáci neseznamovali jen s poznatky, které věda nashromáždila, nýbrž i s povahou vědy jako takové, se dostal do kurikulárních dokumentů až na přelomu osmdesátých a devadesátých let 20. století. Přitom myšlenka, že by se spíš než o výsledcích bádání mělo vyučovat o něm samém, je poměrně stará. Prvně se objevila již v polovině 19 . století (Jenkins, 2014). Doporučení vyučovat o fungování vědy a její povaze šlo tehdy ruku $v$ ruce $s$ návrhem využívat $k$ tomuto účelu dějiny věd. Idea, že by se $k$ výuce o vědě hodily vybrané historické kauzy a př́běhy ze života vědců, se výrazněji prosadila za první světové války ve Velké Británii a následně po druhé světové válce $v$ USA (Taylor \& Hunt, 2014). V obou prípadech ale oslovila spiše odborníky než řadové učitele a celkem rychle zapadla. Jiný zpưsob, jak žákům přibližit fungování vědy, přinesla šedesátá léta 20. století. Anglickým středoškolákům bylo tehdy umožněno zvolit si téma a samostatně na něm provést vlastní výzkum (tzv. Extended Project Qualification). Co obnáší práce vědce, tedy zažili „na vlastní kůži“. Kritikové tohoto př́stupu ale upozorňovali, že se výuka o vědě nedá beze zbytku nahradit jejím provozováním (tamtéž). 
Pokud se ztotožníme s názorem, že je třeba žáky s povahou vědy seznamovat, je nutné si ujasnit, jaká tato povaha je. Porovnáme-li americké kurikulární dokumenty Benchmarks for Science Literacy (1993) a National Science Education Standards (1996), které výuku o vědě jako jedny z prvních požadovaly, ukáže se, že povahu vědy mohou vystihovat protichůdná tvrzení. Pro př́klad uved'me alespoň následující dvojice výroků objevující se v uvedených dokumentech (Good \& Shymansky, 2001, s. 59):

- Pro vědu je typická neustálá proměna. × Pro vědu je typická kontinuita.

- Co pozorovatel předpokládá, že uvidí, také obvykle vidí. × Nezávislý výzkum téhož problému brání zkreslování výsledků vlivem pozorovatele.

- Vědecké obory se liší předmětem studia, používanými technikami i výstupy. × Všechny obory sdílejí společný vědecký základ.

Výše zmíněná hesla o povaze vědy mohou působit dojmem prázdných sloganů a pro žáky nejspíš budou v obecné podobě nepochopitelné. Proto mezi odborníky na výuku o vědě panuje přesvědčení, že je účelné tuto problematiku vyučovat na konkrétních příkladech, jejichž zdrojem jsou dějiny věd.

Využíváme-li dějiny věd jako nástroj pro pochopení principů vědecké práce, hovoríme o instrumentálním argumentu pro jejich výuku (Rutherford, 2001). Výuka dějin věd ale přináši i jiná pozitiva. Budoucím vědcům umožňuje vyhnout se vyzkoušeným slepým uličkám a zbytečnému poznávání již poznaného (Jangl, 2002). Ve školním prostředí jsou dějiny věd užitečné i tím, že propojují jednotlivé přírodovědné předměty a vnášejí do nich emoce, kterých se v nich jinak nedostává (Barth, 1999). Nicméně dějiny věd mají i svoji vlastní hodnotu. Některé historické události totiž představují milníky ve vývoji myšlení, a mají proto význam samy o sobě. Jejich znalost je regulérní součástí přírodovědné gramotnosti. $V$ tomto prrípadě hovoříme o kulturním argumentu ve prospěch výuky dějin věd (Rutherford, 2001).

Výuka o vědě a jejích dějinách začala být více propagována na konci 20 . století mj. kvůli zřetelnému poklesu zájmu amerických i evropských žáků o přírodní vědy. Za jeden z prostředků k opětovnému zvýšení obliby byl pokládán větší dưraz na společenské souvislosti prírodních věd (Bennett, Lubben, \& Hogarth, 2007). Tento přístup, doporučovaný i Evropskou unií, se označuje jako výuka přírodních věd v souvislostech (Science-Technology-Society, STS). Spadají do ní následující témata: přírodní vědy a životní prostředí (udržitelnost), prírodní vědy a technika v každodenním životě, přírodní vědy a lidské tělo, věda a etika, zasazení přírodních věd do jejich společenských a kulturních souvislostí, dějiny přírodních věd a filozofie přírodních věd (EACEA, 2011). V anglicky psané literatuře se pro některá z uvedených témat používají ustálené zkratky: konkrétně HOS - History of Science, HPS - History and Philosophy of Science, HPSS - History, Philosophy and Sociology of Science.

První tři témata (přírodní vědy a životní prostředí, přírodní vědy a technika v každodenním životě, přírodní vědy a lidské tělo) zohledňují prakticky všechny země EU, a to na úrovni primárního i sekundárního vzdělávání. Poslední čtyři témata bývají jako účinný nástroj pro seznámení s povahou vědy doporučována především na úrovni sekundárního vzdělávání. Jmenovitě vědu a etiku zohledňuje na primární 
úrovni zhruba třetina evropských zemí, na sekundární úrovni polovina; na zasazení prírodních věd do jejich společenských a kulturních souvislostí bere ohled na primární úrovni polovina evropských zemí, na sekundární úrovni téměř všechny státy; dějiny př́rodních věd zohledňuje necelá polovina zemí na primární, resp. více než polovina na sekundární úrovni; na filozofii př́rodních věd obrací zřetel na primárním stupni třetina, na sekundárním stupni polovina evropských zemí (tamtéž). Mimo Evropu věnují velkou pozornost výuce historických, filozofických a společenských aspektů vědy zejména USA (Wang \& Schmidt, 2001).

Podnětem pro sepsání této studie byla osobní zkušenost autorky - středoškolské učitelky $s$ vytvářením ŠVP, která $v$ ní vyvolala prvotní dojem, že poznání povahy vědy jako takové není v RVP dostatečně zdůrazněno. Tento impulz vedl $k$ hlubšímu prostudování kurikulárních dokumentů a k zájmu o to, jak uvedenou problematiku řeši jiné země. Jak konstatuje studie Dibattisty a Morgese (2014), ne všechny evropské dokumenty dostatečně zdůrazňují potřebu výuky o vědě, navíc mnoho oficiálně doporučovaných prvků vypadává při tvorbě lokálních kurikul. Autoři zmiňované studie uvádějí řecké, francouzské, britské či italské iniciativy, které se tento stav snaží zvrátit, ve střední Evropě jsou však v tomto ohledu aktivní pouze některé německé univerzity.

Tato stat', nacházející se na pomezí teoretické a přehledové studie, se opírá o instrumentální pojetí dějin vědy, tj. dějiny chápe jako vhodný prostředek $k$ výuce o vědě. Jejím hlavním cílem je popis a následná diskuse, jak je výuka o vědě a jejích dějinách uchopena $v$ kurikulárních dokumentech (v Rámcovém vzdělávacím programu pro základní vzdělávání - RVP ZV a v Rámcovém vzdělávacím programu pro gymnázia - RVP G). Cílem studie tedy není analýza kurikulárních textů v pravém slova smyslu. Cílem je zodpovědět otázky koncepčního charakteru: Je v RVP ZV a RVP $G$ zmíněn požadavek na výuku o vědě? Pokud ano, v souvislosti s jakými vzdělávacími oblastmi a obory je výuka o vědě zmiňována? Jaké konkrétní požadavky kladou $R V P Z V$ a RVP G na výuku o vědě? Doporučují RVP dějiny věd jako prostředek výuky $O$ vědě?

Vedlejším cílem studie je diskutovat české požadavky na výuku o vědě s požadavky zemí, jejichž kurikula výuce o vědě věnují značnou pozornost. (Pro srovnání byly zvoleny USA, Kanada a Velká Británie z důvodů vysvětlených v kapitole 1.) Tento cíl autorka zvolila proto, že neexistuje jednotný, mezinárodně uznávaný pohled na to, co by mělo být součástí výuky o vědě. Chybějící seznam požadavků proto nahradila souhrnem nároků zemí, jež mají ve výuce o vědě dlouhou tradici. $Z$ tohoto srovnání by mělo vyplynout, které požadavky na výuku o vědě v českých kurikulárních dokumentech chybí.

Na základě těchto zjištění autorka s oporou o relevantní odborné zdroje teoretického, koncepčního i empirického charakteru navrhuje vlastní doporučení pro praxi i tvorbu kurikulárních dokumentů. Záměrem je tak reagovat na výzvy spojené s doznívající kurikulární reformou v rámci tematického zaměření tohoto čísla časopisu.

První kapitola textu shrnuje podstatu zaměření této studie, zdůvodňuje volbu zkoumaných zemí a zdrojů informací. Druhá popisuje, jak je výuka o vědě a jejích 
dějinách zohledněna v Česku, třetí porovnává přistup Česka a vybraných zemí k tématu a zamýšlí se nad opatřeními, která by bylo třeba přijmout, aby výuka o vědě a jejích dějinách získala v českých školách větší prostor.

\section{Zaměření studie}

V textech Rámcový vzdělávací program pro základní vzdělávání (RVP ZV; MŠMT, 2017) a Rámcový vzdělávací program pro gymnázia (RVP G; VúP, 2007) hledala autorka pasáže, které odkazují na historické, filozofické a sociologické aspekty vědy (HPSS). Jednalo se o zmínky vztahující se k následujícím tématům: k vlivu věd a technologií na společnost, $\mathrm{k}$ pưsobení společnosti na vědy a technologie, $\mathrm{k}$ dějinám věd a technologií, k povaze vědeckého poznání a principům vědeckého bádání (Wang \& Schmidt, 2001).

Rámcové vzdělávací programy byly zvoleny z toho důvodu, že představují základní dokument, podle něhož učitelé vytvářejí školní vzdělávací programy (ŠVP), které následně rídí jejich výuku. RVP tedy školám pro výuku o vědě vymezují základní manévrovací prostor. Učivo, které k problematice povahy vědy požaduje RVP ZV, chápe autorka jako základ, jejž by o vědě měli vědět všichni žáci, a to bez ohledu na jejich další studijní či vědecké ambice. V RVP G předpokládá větší prostor pro výuku o vědě vzhledem $\mathrm{k}$ tomu, že se od absolventů gymnázií očekává studium na vysoké škole, ke kterému je pokročilejší představa o fungování vědy potřebná.

Požadavky na výuku o vědě a jejích dějinách byly hledány v pojetí a cílech výuky vzdělávacích oblastí Člověk a príroda, Člověk a společnost, Matematika a její aplikace, Informační a komunikační technologie a Člověk a svět práce. Dotýkaly se obsahu předmětů prrírodovědných (učiva biologie, přírodopisu, chemie, fyziky) i jiných (matematiky, IVT, zeměpisu a dějepisu).

Vedle výše popsaného hlavního cíle sledovala studie ještě jeden doplňující: chtěla poukázat na chybějící požadavky na výuku o vědě v českých kurikulárních dokumentech. Pro tento účel bylo využito srovnání s Velkou Británií (resp. Anglií), USA a Kanadou. Cílem nebylo porovnávat tyto země mezi sebou, nýbrž je využít jako protipól Česka. Tato trojice totiž věnuje výuce o vědě a jejích dějinách značnou pozornost (Dibattista \& Morgese, 2014). Kontrast mezi souhrnem jejich požadavků na výuku o vědě a obdobnými českými požadavky může ukázat, které konkrétní aspekty výuky o vědě české kurikulum opomíjí. S ohledem na takto vymezený doplňující cíl nebyla u těchto tří zemí prováděna detailní analýza kurikulárních dokumentů.

Velká Británie, USA a Kanada představují homogenní skupinu. Spojuje je skutečnost, že se jedná o vyspělé anglofonní země, jejichž vzdělávací soustava se od české velmi liší. Jde o státy s tradičně decentralizovaným vzdělávacím systémem, kde je v poslední době patrná snaha o určité sjednocení (Greger, Gröschlová, \& Ježková, 2006). Všechny tři země spojuje dlouhá tradice výuky o vědě pomocí dějin, proto mohou být jejich zkušenosti pro Česko cenné. Uvedené státy spojuje také skutečnost, že v mezinárodním šetření přírodovědné gramotnosti PISA (2015) 
6 dosáhly lepšího výsledku než Česko: USA se umístily v pásmu průměrných výsledků $s$ bodovým ziskem 496, Velká Británie a Kanada $v$ pásmu nadprůměrných výsledků se ziskem 509, resp. 528 bodů. Průměr zemí OECD odpovídal 493 bodům, což byla také hodnota, které dosáhlo Česko (Blažek \& Př́hodová, 2016). Poměřujeme-li tedy tyto země s Českem, jde o srovnávání dosti odlišných systémů. Pokud bychom je poměřovali mezi sebou, jedná se o komparaci nejméně odlišných systémů (Rabušicová \& Záleská, 2016).

U výše zmíněných zemí se článek opírá o studie organizace International History, Philosophy and Science Teaching Group (IHPST), která sbírá informace o prístupu $k$ výuce o vědě (včetně jejích dějin či filozofie) v jednotlivých zemích světa. Využité studie vždy analyzovaly situaci $\vee$ jedné konkrétní zemi. Jako doplňkový zdroj byly využity publikace organizace Eurydice shromažd'ující informace o vzdělávacích soustavách členských zemí EU. V textu článku je u sledovaných zemí vždy uveden dokument, o nějž se daná země opírá, a principy, které s ohledem na výuku o vědě uvádí.

\section{Výuka o vědě a jejích dějinách v Česku}

RVP ZV (MŠMT, 2017) výuku o vědě ani dějiny věd přímo nezmiňuje. Nicméně některé dovednosti, které jsou pro vědecké bádání typické, jsou součástí kličových kompetencí: konkrétně jde o kompetence k učení (samostatné pozorování a experimentování, porovnávání výsledků, vyvozování závěrů apod.) a k řešení problémů (vyhledávání informací, volba vhodného postupu, obhájení vlastního postupu apod.).

$\checkmark$ charakteristice vzdělávací oblasti Člověk a príroda je výslovně zdůrazněno, že by si žáci měli osvojit důležité dovednosti, které souvisí se zkoumáním přírody:

Jedná se především o rozvíjení dovednosti soustavně, objektivně a spolehlivě pozorovat, experimentovat a měřit, vytvářet a ověřovat hypotézy o podstatě pozorovaných prírodních jevů, analyzovat výsledky tohoto ověřování a vyvozovat z nich závěry. Žáci se tak učí zkoumat příčiny prírodních procesů, souvislosti či vztahy mezi nimi, klást si otázky (Jak? Proč? Co se stane, jestliže?) a hledat na ně odpovědi, vysvětlovat pozorované jevy, hledat a řešit poznávací nebo praktické problémy, využívat poznání zákonitostí přírodních procesů pro jejich předvídání či ovlivňování. (MŠMT, 2017, s. 62)

V učivu př́rodopisu je $v$ souvislosti s praktickým poznáváním prírody uvedeno téma významní biologové a jejich objevy (tamtéž, s. 73). Jde ale o izolovanou zmínku, žádné očekávané výstupy s ní nejsou spjaté.

V dějepisu (vzdělávací oblast Člověk a společnost) najdeme jedno místo, které alespoň nějak odkazuje $k$ dějinám vědy, resp. techniky. Jedná se o očekávaný výstup moderních dějin, podle něhož má žák poukázat na konkrétní situace, kdy byla ve světových válkách zneužita technika (tamtéž, s. 56).

Dalši vzdělávací oblastí, která s výukou o vědě souvisí, je Matematika a její aplikace. $V$ ní se žáci učí správně měřit, zaokrouhlovat naměřené hodnoty, porovnávat je a dále s nimi počítat. Učí se analyzovat tabulky a grafy a obdobné grafické výstupy samostatně vytvářet. Výuka matematiky má mj. za cíl vést žáky $\mathrm{k}$ logickému 
myšlení, věcné argumentaci, stručnému vyjadřování pomocí matematických symbolů a schopnosti adekvátně využívat výpočetní techniku (tamtéž, s. 30). Pro výuku o vědě je zásadní také požadovaný nácvik rozboru problému, volby vhodného postupu, naplánování dílčích kroků směřujících $\mathrm{k}$ vyřešení problému a kontroly dosažených výsledků. $V$ neposlední řadě jde i o vyjadřování skutečnosti matematickým zápisem, rozpoznání př́nosu i limitů zvoleného matematického modelu a uvědomění, že žádný model nevystihuje celou skutečnost.

$K$ výuce o vědě přispívá také vzdělávací oblast Informační a komunikační technologie, a to požadavkem, aby žáci v zájmu větší věrohodnosti zjištěných informací využívali více informačních zdrojů (tamtéž, s. 38).

$\checkmark$ některých tematických okruzích se výuky o vědě dotýká i vzdělávací okruh Člověk a svět práce. Jde především o práci s laboratorní technikou, při níž žák volí vhodný postup a pomůcky pro konkrétní pokus, vytváŕí protokol a prezentuje v něm dosažené výsledky a z nich vyplývající závěry (tamtéž, s. 103).

RVP G (VúP, 2007) apeluje na školy, aby se nesnažily předat studentům co největší objem dílčích poznatků, nýbrž aby jim nabídly patřičnou strukturu vědění (tamtéž, s. 8). Řada zásad vědecké práce je vtělena do podoby klíčových kompetencí: jedná se zejména o kompetence $k$ řešení problémů (požadavek, aby studenti uměli vytvářet hypotézy, ověřovat je, formulovat argumenty, posoudit př́nos a rizika určitého řešení apod.), které jsou doplněny jednotlivými kompetencemi komunikativními (umět s porozuměním používat odborný jazyk) a kompetencemi k učení (kriticky přistupovat ke zdrojům informací).

Podle vzdělávací oblasti Člověk a príroda by studenti gymnázia měli samostatně a ve větší míře než žáci základní školy hledat zákonitosti a souvislosti mezi prírodními jevy (tamtéž, s. 25). Jak naznačuje následující citace, od studentů gymnázií se očekává seznámení s metodologií prírodovědného poznávání, její osvojení a využívání. Zamyšlení nad tím, co je pro př́rodovědný přístup ke světu charakteristické, se od nich ale nevyžaduje:

Přírodovědné disciplíny jsou si velmi blízké i v metodách a prostředcích, které uplatňují ve své výzkumné činnosti. Používají totiž vždy souběžně empirické prostředky (tj. soustavné a objektivní pozorování, měření a experimenty) a prostředky teoretické (pojmy, hypotézy, modely a teorie). Každá z těchto složek je přitom v procesu výzkumu nezastupitelná, vzájemně se ovlivňují a podporují. Žáci mají mít proto co nejvíce příležitostí postupně si osvojovat vybrané empirické i teoretické metody přírodovědného výzkumu, aktivně je spolu s přírodovědnými poznatky ve výuce využívat, uvědomovat si důležitost obou pro přírodovědné poznání, předně pak pro jeho objektivitu a pravdivost i pro řešení problémů, se kterými se člověk při zkoumání přírody setkává. (VúP, 2007, s. 26)

Také další pasáž dosvědčuje, že RVP G požaduje hlavně osvojení př́rodovědeckého přístupu k problémům, at' už se jedná o odbornou kritiku, či nakládání s údaji:

Gymnaziální přírodovědné vzdělávání musí proto též vytvářet prostředí pro svobodnou diskusi o problémech i pro ověřování objektivity a pravdivosti získaných nebo předložených prírodovědných informací. Lze toho dosahovat tím, že si žáci osvojují např. 
pravidla veřejné rozpravy o způsobech získávání dat či ověřování hypotéz, rozvíjejí si schopnost předložit svůj názor, poznatek či metodu k veřejnému kritickému zhodnocení, uči se nevnímat oponenta pouze jako názorového protivníka, ale i jako partnera při společném hledání pravdy. K základním morálním normám př́rodovědného poznávání patři především požadavek nezkreslovat data získávaná ve výzkumu a nevyužívat jeho výsledky pro vytváření technologií a dalších praktických aplikací, které by mohly poškozovat zdraví člověka či nevratně narušit přírodní a sociální prostředí. Žákům je tak zapotřebí na konkrétních případech ukazovat negativní důsledky zkreslování výzkumných dat či využívání výsledků přírodovědného výzkumu pro účely potenciálně ohrožující člověka a další složky přírody. (VúP, 2007, s. 26)

Vzdělávací oblast Člověk a společnost si mj. klade za cíl podporovat úctu k intelektuálnímu bohatství lidstva (tamtéž, s. 38) a vést studenta k pochopení proměnlivosti pohledu na svět v různých fázích jeho vývoje (tamtéž, s. 39). Nicméně v očekávaných výstupech najdeme pouze jediný požadavek, který souvisí s dějinami věd. Student má identifikovat nové myšlenky z období renesance a novověku a posoudit jejich dopad (tamtéž, s. 44). ${ }^{2}$

V charakteristice vzdělávací oblasti Matematika a její aplikace se připomíná, že je matematika spjata s mnoha významnými historickými osobnostmi (tamtéž, s. 21). S ohledem na výuku o vědě má tato oblast stejné cíle jako základní vzdělávání:

Matematické vzdělávání napomáhá rozvoji abstraktního a analytického myšlení, rozvíjí logické usuzování, uči srozumitelné a věcné argumentaci s cílem najít spíše objektivní pravdu než uhájit vlastní názor. Těžiště výuky spočivá v osvojení schopnosti formulace problému a strategie jeho řešení, v aktivním ovládnutí matematických nástrojủ a dovedností, v pěstování schopnosti aplikace. Matematika přispívá $\mathrm{k}$ tomu, aby žáci byli schopni hodnotit správnost postupu při odvozování tvrzení a odhalovat klamné závěry. (VúP, 2007, s. 22)

Vzdělávací oblast Informatika a informační a komunikační technologie po studentech mj. požaduje zlepšování orientace v množství informací a využívání techniky pro jejich pokročilejší zpracování i pro modelování přírodních jevů (tamtéž, s. 62-63).

2 Pokud by chtěl středoškolský učitel hledat inspiraci $k$ výuce o vědě pomocí jejích dějin na metodickém portálu RVP (www.rvp.cz), zjistí, že materiálů na toto téma je zde poskrovnu, přičemž většina bývá zaměřena na určitého vědce. V létě 2017 byly v sekci Člověk a příroda, určené pro gymnázia, k dispozici dva články (Schrödinger, Gamow a Kaku: Jak učit fyziku zajímavěji?, F. A. Kekulé) a jeden DUM (Jak dostaly jednotky svá jména). Pomineme-li dva materiály o českých cestovatelích (Po stopách F. A. Elstnera, Po stopách Hanzelky a Zikmunda v Africe), nebyl zde žádný e-learning a učitel mohl využít pouhých šest odkazů na webové stránky (Souhrnné vydání celoživotního díla Charlese Darwina; Slavní matematici, fyzici a vynálezci; Albert Einstein; Ernest Rutherford; Dějiny kartografie; Nobelova cena - oficiální stránky). 


\section{Diskuse - porovnání situace v Česku a zahraničí, doporučené změny}

Jak vyplývá z výše citovaných pasáži RVP, požadavky českého základního vzdělání na výuku o vědě se zaměřují na to, aby si žáci osvojili základní dovednosti typické pro př́rodovědné bádání. To je samo o sobě velký cíl, který podle mínění autorky nemá smysl komplikovat požadavkem na reflexi tohoto způsobu poznávání, a proto popsaný stav pokládá za odpovídající pro základní školu. Očekávala by ale, že nároky kladené na gymnazisty budou v tomto ohledu větší. Gymnaziální RVP nicméně opět požaduje především to, aby byli studenti při zkoumání přírodních jevů schopni postupovat podle obvyklých vědeckých postupů (byt' ve větší míře a samostatněji než žáci základní školy). Oproti žákům základní školy by měli mít povědomí o morálních zásadách, které musí vědci při výzkumech respektovat, a o odpovědnosti, kterou mají vưči společnosti a životnímu prostředí. Hlubší reflexe zpưsobu bádání se ale od studentů nečeká $a$ ani se nepožaduje, aby si uvědomovali neukončenost vědeckého poznání a jeho proměnlivost $v$ čase. Mưžeme tedy říci, že nároky gymnaziálního vzdělávání jsou oproti základní škole navýšeny, ale nikoli dostatečně.

Zajímavé je srovnání situace ve výuce o vědě v Česku a v anglofonních zemích - USA ${ }^{3}$, Kanadě 4 a Velké Británii ${ }^{5}$. Hlavní poučení o vědě, s nimiž by se britští, američtí a kanadští žáci měli ve škole setkat, shrnuje tabulka 1 (podle McComas, 2014; Metz, 2014; Taylor \& Hunt, 2014). Požadavky těchto zemí můžeme roztř́ídit do následujících okruhư: žáci by si měli uvědomovat nejistotu vědeckého poznání (řádek 1) a jeho proměnlivost $v$ čase (rádek 5). Oba tyto požadavky reflektují povahu vědeckého poznání, v českém prostředí, bohužel, chybí. Další okruh požadovaný $v$ uvedených zemích se orientuje na vědu jako na společenskou aktivitu, jmenovitě rádek 3 upozorňuje na potřebu spolupráce vědců, raádek 6 na společenské dopady výsledků vědy a řádek 4 na vztah vědy $\mathrm{k}$ technologiím.

3 Nejnovějším dokumentem vztahujícím se k výuce věd v USA je Framework for $K$ - 12 Science Education: Practices, Crosscutting Concepts and Core Ideas (vydaný NRC v roce 2012). Doporučení uvedená $v$ tomto dokumentu byla $z$ velké části začleněna do vzdělávacích standardů Next Generation Science Standards (NGSS), které má většina států USA v úmyslu přijmout. Rozdíly v kurikulárních dokumentech jednotlivých států jsou nicméně pořád velké (McComas, 2014).

4 V Kanadě vznikl počátkem devadesátých let dokument Common Framework of Science Learning Outcomes zamýšlený jako vodítko, podle kterého si budou provincie upravovat své vlastní vzdělávací standardy. Jako jedno z důležitých témat tento dokument zavedl vztah vědy, technologie, společnosti a prostředí, tzv. STSE (Metz, 2014).

5 Velká Británie má z evropských zemí za sebou nejdelší řadu pokusů o začlenění dějin věd do výuky. Závazný dokument pro anglické a velšské školy, který jako první požadoval vyučovat i o povaze vědy a jejích dějinách, byl schválen roku 1989. Avšak z jeho pozdějších úprav tyto požadavky téměř zmizely. Reformní návrh anglického kurikula byl schválen roku 2004 (s pozdějšími specifikacemi AQA GCSE Science Specifications a OCR Twenty First Century Science Specification) a ve výuce věd rozlišuje jednak oblast znalostí a porozumění, a jednak povědomí o tom, jak věda funguje (Taylor \& Hunt, 2014). Nicméně v tom, co se $z$ této problematiky má konkrétně vyučovat, nepanuje $v$ reálu shoda. (Poučení o vědě, která byla v průzkumu mezi britskými vědci, historiky, filozofy, sociology vědy a učiteli prírodovědných předmětů označena za stěžejní, shrnuje tabulka 1.) 
10 Tabulka 1 Důležitá poučení, která by měli žáci mít o vědě (shrnutí obsahu vybraných koncepčních dokumentů)

\begin{tabular}{|c|c|c|c|c|}
\hline & USA & Velká Británie & Kanada & Česko \\
\hline 1 & $\begin{array}{l}\text { Vědecké závěry } \\
\text { jsou do určité míry } \\
\text { nejisté. }\end{array}$ & $\begin{array}{l}\text { Část soudobého } \\
\text { vědění je velmi } \\
\text { dobře podložená, } \\
\text { zatímco o jiné se } \\
\text { dá pochybovat. } \\
\text { V budoucnu se } \\
\text { naše poznání může } \\
\text { změnit, bud' kvůli } \\
\text { novým důkazům, } \\
\text { nebo kvưli nové } \\
\text { interpretaci starých } \\
\text { důkazů. }\end{array}$ & & \\
\hline 2 & $\begin{array}{l}\text { Velký význam má } \\
\text { experimentování. } \\
\text { Věda spočívá } \\
\text { na empirických } \\
\text { důkazech. } \\
\text { Pozorování a z nich } \\
\text { vyvozené závěry jsou } \\
\text { dvě různé věci. }\end{array}$ & $\begin{array}{l}\text { Ve vědě se využivá } \\
\text { experimentů, } \\
\text { k doložení nějakého } \\
\text { tvrzení obvykle } \\
\text { nestačí provést jen } \\
\text { jeden experiment. } \\
\text { Získané údaje je } \\
\text { třeba interpretovat. } \\
\text { Stejné údaje mohou } \\
\text { vést k různým } \\
\text { interpretacím. } \\
\text { Vědci mají výchozí } \\
\text { předpoklady, } \\
\text { vytvářejí si hypotézy. } \\
\text { Ve vědě se používá } \\
\text { mnoho různých } \\
\text { metod a přístupů. } \\
\text { Je nezbytné si } \\
\text { neustále klást otázky } \\
\text { a hledat na ně } \\
\text { odpovědi. Důležité } \\
\text { jsou představivost } \\
\text { a kreativita. }\end{array}$ & $\begin{array}{l}\text { Žák má popsat } \\
\text { procesy, pomocí } \\
\text { nichž se věda } \\
\text { a technika snaží } \\
\text { pochopit přírodní } \\
\text { úkazy. }\end{array}$ & $\begin{array}{l}\text { Věda využivá } \\
\text { empirické } \\
\text { i teoretické metody, } \\
\text { které se navzájem } \\
\text { doplňují. } \\
\text { Vědci kriticky } \\
\text { hodnotí dostupné } \\
\text { informace, formulují í } \\
\text { hypotézy a následně } \\
\text { je ověřují. } \\
\text { Údaje by neměly být } \\
\text { zkreslovány. }\end{array}$ \\
\hline 3 & $\begin{array}{l}\text { Ve vědě je zásadní } \\
\text { spolupráce. }\end{array}$ & $\begin{array}{l}\text { Vědci často } \\
\text { pracují v týmech } \\
\text { (multidisciplinárních } \\
\text { a mezinárodních). } \\
\text { Než jsou určité } \\
\text { závěry přijaty, jsou } \\
\text { kriticky posuzovány } \\
\text { vědeckou komunitou. }\end{array}$ & & $\begin{array}{l}\text { Vědci vystavují své } \\
\text { závěry odborné } \\
\text { kritice, při které } \\
\text { věcně argumentují. }\end{array}$ \\
\hline
\end{tabular}


4 Věda a technologie nejsou totéž.
5

6
Žák má rozlišovat

mezi vědou

a technologií

z hlediska jejich cílů, výsledků a hodnot.

Má vysvětlit jejich

vzájemnou interakci.

Vědecké poznání se vyvíjí.
Žák má popsat

vývoj vědeckých

teorií a technologií

$v$ historii.

Žák má analyzovat

sociální záležitosti

vztahující se

$\mathrm{k}$ aplikacím vědy

a technologií,

př́padně $k$ jejich

omezením. Má

vysvětlit výhody

a nevýhody určitého

řešení z hlediska

jeho udržitelnosti.

Pozn.: Upraveno podle McComas (2014) - pohled amerických kurikulárních dokumentů (poučení uváděná ve více než $80 \%$ státních kurikul), Taylor a Hunt (2014) - názor britské odborné veřejnosti, Metz (2014) - kanadské očekávané výstupy. Formulace nejsou v pưvodním znění, byly kráceny. Poučení pro Česko formulovala autorka článku na základě citovaných pasáží z RVP G (2007).

Tabulka 1 dokládá, že požadavky na výuku o vědě jsou v jednotlivých zemích formulovány odlišně. Šest výše vymezených oblastí nepokrývá kompletně ani jedna ze zmíněných zemí. Z požadavků je nejvíce akcentováno povědomí o vědeckých metodách a charakteru vědecké práce (řádky 2 a 3). V Česku nabádá k ukazování (negativních) potenciálních dopadů vědeckých výtvorů na společnost pouze gymnaziální RVP, potřebu spolupráce spiše naznačuje, než že by ji přímo zmiňoval. Obdobně problematika vztahu vědy a technologií se dá z textu RVP $G$ spiš vytušit, než že by byla skutečně zohledněna. USA, Velká Británie i Kanada uvádějí shodně pouze jediný požadavek. Aby žáci znali obvyklý postup získávání údajů a vyvozování závěrů z nich (řádek 2). Jde o způsob vědeckého poznávání, a to je právě hlavní oblast, na kterou se soustředí oba české RVP.

Výše uvedené potvrzuje krátkou zmínku ve zprávě Eurydice (EACEA, 2011), podle které je $v$ českém školství zohledněna mj. problematika vztahu vědy $\mathrm{k}$ životnímu prostředí, $\mathrm{k}$ běžně užívaným technologiím, $\mathrm{k}$ fungování lidského těla a $\mathrm{k}$ etickým záležitostem, ale sociální kontext vědy, filozofie a dějiny věd nikoli. Přitom evropské dokumenty již relativně dlouho reflektují krizi ve výuce př́rodních věd a technických oborů (European Commission, 1995; Gago et al., 2004; Rocard et al., 2007) a vedle důrazu na praktické činnosti, problémovou a badatelskou výuku nabízejí jako pro- 
12 tiopatření více si všímat sociálních souvislostí vědy a zlepšovat povědomí učitelů o tomto tématu (EACEA, 2011). Je škoda, že Česko tuto výzvu ve svých RVP ignoruje.

$S$ ohledem na výše zmíněné považuje autorka za vhodné historické, filozofické a společenské aspekty vědy do středoškolské výuky výrazněji začlenit, a to nejlépe využíváním príikladů $z$ dějin věd ve výuce příslušných předmětů ( $v$ biologii, chemii, fyzice, zeměpisu či dějepisu). Naukové předměty ale bývají z hlediska vzdělávacího obsahu velmi konzervativní (Janík et al., 2010). Máme-li stručně shrnout hlavní argumenty ve prospěch přijetí nového učiva, mưžeme uvést toto:

Změny v kurikulu se dají zdůvodňovat bud' konjunkturálně, nebo principiálně (Štech, 2013). Konjunkturálně motivované změny mají přinést prospěch, jsou vedené např́klad snahou zlepšit výsledky dané země v nějakém mezinárodním testování, motivovat žáky ke studiu určitých oborů nebo vyhovět požadavkům zaměstnavatelů na profil absolventů. Požadavek na výuku dějin věd můžeme konjunkturálně obhájit: již v šedesátých letech prokázala práce L. Klopfera a W. Cooleyho (1961), že výuka prírodních věd $v$ jejich historických souvislostech zvyšuje zájem žáků o prírodovědný výzkum, navíc existuje vazba mezi skutečností, že přírodní vědy žáky baví, a jejich výsledky v prrírodovědných testech (EACEA, 2011).

Principiální zdůvodnění se opírá o hodnoty, které daná společnost pokládá za zásadní. Předávané učivo by mělo tyto hodnoty nést samo v sobě (Štech, 2013, s. 616). I z principiálního hlediska nové učivo obstojí: požadovanou cennost v př́padě výuky o vědě a jejích dějinách mưžeme spatřit $v$ metakognitivním nadhledu, který reflexe vědeckého pohledu na svět přináší.

Shodneme-li se, že je vytvoření většího prostoru pro výuku o vědě (ve smyslu HPSS) potřebné, je třeba zvážit následující opatření:

Výuku o vědě je nutné více zohlednit ve středoškolských kurikulárních dokumentech. Proto je nezbytné si nejprve ujasnit, co konkrétně se má v rámci této problematiky vyučovat. Při výběru ponaučení, která by měla škola žákům zprostředkovat, je možné se inspirovat $v$ zahraničních kurikulárních dokumentech (např. ve výše zmiňovaných amerických), nebo po vzoru Anglie provést mezi odbornou veřejností (vědci, učiteli, didaktiky, historiky, filozofy a sociology vědy) průzkum, jehož výsledkem by byl souhrn stěžejních poučení o vědě.

Za předpokladu zachování stávající struktury RVP $G$ by měla být ve vzdělávacím obsahu zdůrazněna opomíjená témata: vliv věd a technologií na společnost, působení společnosti na vědy a technologie, povaha vědeckého poznání a jeho dějinný vývoj. Promítnout by se měla nejen do učiva, ale také do očekávaných výstupů, a to ve všech dotčených vzdělávacích oblastech.

Začlenění výuky o vědě do kurikulárních dokumentů je zásadní, nicméně samo o sobě nepostačující opatření. Jak velký může být rozdíl mezi zamýšleným a realizovaným kurikulem, ilustruje situace v Itálii: reformní dokument PECUP (Profilo educativo, culturale e professionale dello studente) od výuky vyžaduje zohlednění historického rozměru vědění, přesto učitelé dějinám věd moc prostoru nevěnují. Chybí jim odpovídající materiály, navíc sami dějiny věd přiliš neovládají, protože tato problematika nebyla povinnou součástí jejich studia (Dibattista \& Morgese, 
2014). Že nejde pouze o specifikum Itálie, dosvědčuje také osobní zkušenost učitelů

z Francie a Německa, tj. ze zemí, které mají ve svých kurikulárních dokumentech výuku o vědě pomocí jejích dějin zohledněnu. I oni konstatují, že jsou na vysoké škole pro budoucí učitele dějiny věd pouze volitelné, že učebních materiálů $z$ dějin věd není dostatek (Fauque, 1999), a proto pedagogům chybí potřebné znalosti, dějiny věd neradi učí a obvykle jim věnují jen minimum pozornosti (Barth, 1999).

Od otázky, co o vědě vyučovat, se tedy dostáváme k otázce, jak výuku v praxi zajistit. Jak bylo $v$ úvodu vysvětleno, jako vhodný nástroj $k$ výuce o vědě byly opakovaně doporučovány dějiny věd. První pokusy proběhly v Anglii již za první světové války, záhy však ztroskotaly na neznalosti učitelů (Heilbron, 1999). I nedávná britská zkušenost potvrzuje, že pedagogové těmto tématům moc nerozumí, a když už se o výuku o vědě pokusí, obvykle se omezí jen na její sociální aspekty (Taylor \& Hunt, 2014). Je tedy zřejmé, že mají-li učitelé dějiny věd vyučovat, musí být s požadovanou problematikou obeznámeni (Wang \& Schmidt, 2011).

Někteří autoři proto nabádají organizovat kurzy, kde by se učitelé z praxe s dějinami věd seznámili (Dibattista \& Morgese, 2014). Cílovou skupinou by měli být nejen učitelé přírodovědných předmětů, ale i vyučující dějepisu, kteří dosud dějiny věd opomíjejí (Barth, 1999). V Česku pořádá obdobné semináře cílené i na středoškolské učitele Společnost pro dějiny věd a techniky (Folta, 2002), ve větším měřitku se jí ale nedaři $k$ tématu přitáhnout pozornost.

Je také třeba vzít v úvahu, že jednorázové seznámení s problematikou stěží zajistí její pochopení, natožpak ovlivnění učitelovy práce ve výuce. Požadovaný efekt přinese spíš dlouhodobý kontakt s dějinami věd. Systémovým řešením by proto mohla být osvěta zaměřená na ty, kteři se na učitelskou dráhu teprve připravují. Dějinám věd ale, bohužel, není ve studijních plánech učitelských oborů věnována valná pozornost: napríklad $v$ akademickém roce 2016/2017 byly ve studijních programech učitelských aprobací na Př́rodovědecké fakultě Univerzity Karlovy (www.natur.cuni .cz) dějiny věd pouze mezi volitelnými předměty.

To, že nejde o české specifikum, nýbrž o celoevropský jev, doložila konference evropských akademií věd sdružených do uskupení ALLEA, která se konala v roce 1998 ve Štrasburku (Folta, 1999). Konference jasně ukázala, že dějiny věd mívají okrajové postavení i na vysokých školách, přičemž na středoškolské úrovni bývá jejich výuka věcí osobního nadšení jednotlivých pedagogů (tamtéž; Jangl, 2002). Je možné, že přeplněnost studijních plánů bude i nadále bránit, aby dějiny věd získaly své místo, nicméně podle názoru J. L. Heilbrona (1999) by bylo naprosto legitimní vypustit některé specializované přenášky, aby pro ně vznikl dostatečný prostor. Lépe využít potenciál dějin věd se nedaří ani navzdory činnosti organizací International History, Philosophy and Science Teaching Group (http://ihpst.net) a European Society for the History of Science (www.eshs.org).

Kromě změny ve vysokoškolské prípravě učitelů by kvalitnější výuce o vědě prostřednictvím jejích dějin pomohla dostupnost učebních podkladů (Jangl, 2002). Největší množství výukových materiálů je $v$ angličtině. Pro mladší generaci učitelů by neměl být problém jim rozumět, nicméně těžko můžeme očekávat, že si budou 
14 cizojazyčné materiály sami upravovat do podoby využitelné $v$ jejich vlastní výuce. Řešením může být bud' vytvoření učebních materiálů šitých na míru českému prostředí, anebo převzetí a úprava cizojazyčných materiálů, které by učitelům mohl zpř́stupnit např́klad portál RVP.

Z dlouhodobého hlediska je třeba také zvážit obsah učebnic (McComas, 2014). Jak konstatuje D. Fauque (1999), ve francouzských učebnicích fyziky a chemie bývají pouze stručné biografické poznámky o významných vědcích a lineární výčet jejich objevů. Obdobný stav odhalil i průzkum portugalských učebnic fyziky (Leite, 2002). Nicméně učitelé bývají s tímto stavem srozuměni a vydavatele nic nenutí dějinám věd $v$ učebnicích věnovat více péče (Fauque, 1999).

Nedostatky, které se v učebnicovém podání vývoje vědy nejčastěji objevují, ukazuje na př́kladu českých učebnic biologie Hájková (2017): učebnice se soustředí převážně na zjištěná fakta, průběhu vědeckého bádání věnují jen nečetné zmínky, obvykle mimo hlavní text. Málokdy jsou popsány okolnosti, které daný objev umožnily, většina učebnic jen konstatuje, že k objevu došlo. Učební texty často opomíjejí jak vývoj souvisejících technologií, tak nové přístupy k výkladu již známých jevů. Objevy většinou spojují s výjimečným jednotlivcem, o jehož intelektuálním zázemí a předchůdcích si z textu nelze udělat patřičnou představu. Toto zjištění koresponduje se skutečností, že ani jeden ze sledovaných českých RVP neupozorňuje na týmový charakter vědecké práce (řádek 3 v tabulce 1 ), nezabývá se vztahem mezi vědou a technologiemi (řádek 4) ani nezdůrazňuje proměnlivost a vývoj vědy (ř́dek 5). Pokud se učebnice snaží zachytit vývoj vědy, a nikoli jen jednotlivé nesouvisející epizody z historie, vyvolává obvykle jeho popis dojem postupného hromadění poznatků, které naprosto neproblematicky ústí v současný vědecký pohled na svět (tamtéž). Tím se opomíjí další aspekt výuky o vědě, který chybí i ve sledovaných RVP - nejistota (nedefinitivnost) vědeckého poznání (rádek $1 \vee$ tabulce 1 ).

Shrneme-li výše uvedené, výuka o vědě a jejích dějinách se může v každodenní výuce prosadit jen tehdy, budou-li pro ni vytvořeny odpovídající podmínky. Nejprve je nutné si ujasnit, co by měli žáci o vědě vědět, tyto požadavky zanést do kurikulárních dokumentů a zároveň na jejich výuku učitele po obsahové i metodické stránce připravit (at' již formou dalšího vzdělávání, větším důrazem na filozofii a dějiny věd ve studijních programech učitelských oborů, nebo zpř́stupněním vhodných výukových materiálů).

\section{Závěr}

Uvážíme-li, že jsou v dnešní době vědecké vymoženosti a technologie běžnou součástí našeho světa, je význam prírodovědné gramotnosti zřejmý. Součástí přírodovědné gramotnosti je také porozumění povaze vědy (jejím principưm, možnostem i limitům). $K$ předání tohoto typu informací využívá řada západních zemí dějin věd. Historie totiž obecným poučkám o vědě poskytuje konkrétní př́klady, díky nimž jsou pro žáky srozumitelné. Záměrem tohoto článku bylo upozornit na ignorování dějin 
věd v českých kurikulárních dokumentech. Tento stav kontrastuje s prístupem sledovaných anglofonních zemí, v nichž má výuka o vědě pomocí dějin tradici.

Požadavky českých RVP ZV a RVP G se soustředí především na osvojení zásad, které vědci při bádání dodržují. Ostatní požadavky, které bývají součástí výuky v Anglii a Angloamerice, české kurikulum bud' neobsahuje vůbec (např. povědomí o proměnlivosti a nedefinitivnosti vědeckého poznání), nebo je zahrnuje v nedostatečné míře (povědomí o vztahu světa vědy a společnosti).

Vzhledem k tomu, že ve výše uvedených českých dokumentech o dějinách věd téměř nenajdeme zmínku, pokládáme za vhodné tento vzdělávací obsah v nové úpravě českého kurikula zohlednit. Upozorňujeme však, že samotné dopsání učiva do RVP nestačí. Aby mohli učitelé výuce o vědě a jejích dějinách věnovat adekvátní pozornost, je nezbytné je $v$ této problematice proškolit (resp. pro ni vytvořit prostor ve vysokoškolském studiu budoucích učitelů) a školám poskytnout dostatek vhodných učebních materiálů.

\section{Literatura}

Barth, M. (1999). Dějiny vědy na střední škole: Zkušenosti z mé třídy a úvahy o jejich zařazení do vzdělávání učitelů. DVT, 32(1), 37-48.

Bennett, J., Lubben, F., \& Hogarth, S. (2007). Bringing science to life: A synthesis of the research evidence on the effects of context-based and STS approaches to science teaching. Science Education, 91(3), 347-370.

Blažek, R. (2017). Publikace s uvolněnými úlohami z mezinárodního šetření PISA 2015. Praha: Česká školní inspekce.

Blažek, R., \& Příhodová, S. (2016). Mezinárodní šetření PISA 2015. Národní zpráva. Přírodovědná gramotnost. Praha: Česká školní inspekce.

DeBoer, G. E. (2014). Joseph J. Schwab: His work and his legacy. In M. R. Matthews (Ed.), International handbook of research in history, philosophy and science teaching (s. 2433-2458). Dordrecht: Springer.

Dibattista, L., \& Morgese, F. (2014). Incorporation of HPS/NOS content in school and teacher education programmes in Europe. In M. R. Matthews (Ed.), International handbook of research in history, philosophy and science teaching (s. 2083-2117). Dordrecht: Springer.

EACEA \& Eurydice. (2011). Přírodovědné vzdělávání v Evropě: Politiky jednotlivých zemí, praxe, výzkum. Brusel: Eurydice. Dostupné z http://eacea.ec.europa.eu/education/Eurydice /documents/thematic_reports/133CS.pdf

European Commission. (1995). Teaching and learning: Towards the learning society. Luxembourg: Office for Official Publications of the European Communities. Dostupné z http:// europa.eu/documents/comm/white_papers/pdf/com95_590_en.pdf

Faltýn, J., Nemčíková, K., \& Zelendová, E. (2010). Gramotnosti ve vzdělávání. Praha: vúP.

Fauque, D. (1999). Uvedení do dějin vědy a techniky na středních školách ve Francii. DVT, $32(1), 25-36$.

Folta, J. (1999). Vyučování dějinám věd a techniky aneb Co se začarovaným kruhem. DVT, $32(1), 1-4$.

Folta, J. (2002). Devatenáctý seminář pro vyučující dějinám věd a techniky na českých a slovenských vysokých a středních školách. DVT, 35(3-4), 236-237.

Gago, J. M., Ziman, J., Caro, P., Constantinou, C. P., Davies, G., Parchmannn, I., ... Sjøberg S. (2004). Europe needs more scientists. Luxembourg: Office for Official Publications of the European Communities. Dostupné z https://www. researchgate.net 
/publication/259705752_Europe_Needs_More_Scientists_Report_by_the_High_Level _Group_on_Increasing_Human_Resources_for_Science_and_Technology

Good, R., \& Shymansky, J. (2001). Nature-of-science literacy in benchmarks and standards: Post-modern/relativist or modern/realist? In F. Bevilacqua, E. Giannetto, \& M. Matthews (Eds.), Science education and culture: The contribution of history and philosophy of science (s. 53-65). Dordrecht: Kluwer Academic Publishers.

Greger, D., Gröschlová, A., \& Ježková, V. (2006). Analýza školního vzdělávání ve vybraných zemích EU. Orbis scholae, 0(1), 30-45.

Hájková, J. (2017). Dějiny prrírodních věd: Jejich místo ve škole a v učebnicích biologie. Scientia in educatione, 8(2), 1-13.

Heilbron, J. L. (1999). Ponaučení z výuky dějinám věd. DVT, 32(1), 5-18.

Jangl, L. (2002). K otázce výuky dějin věd a techniky. DVT, 35(1), 37-47.

Janík, T., Maňák, J., Knecht, P., \& Němec, J. (2010). Proměny kurikula současné české školy: Vize a realita. Orbis scholae, 4(3), 9-35.

Jenkins, E. W. (2014). E. J. Holmyard and the historical approach to science teaching. In M. R. Matthews (Ed.), International handbook of research in history, philosophy and science teaching (s. 2381-2432). Dordrecht: Springer.

Klopfer, L., \& Cooley, W. (1961). Use of case histories in the development of student understanding of science and scientists. Cambridge: Graduate School of Education, Harvard University.

Leite, L. (2002). History of science in science education: Development and validation of a checklist for analysing the historical content of science textbooks. Science \& Education, 11(4), 333-359.

Maršák, J., Janoušková, S., Svobodová, J., \& Pumpr, V. (2011). Přírodovědná gramotnost srovnávací analýza 1., 2. Dostupné z http://clanky.rvp.cz/clanek/c/Z/10967/prirodovedna -gramotnost-srovnavaci-analyza-1.-cast.html/; http://clanky.rvp.cz/clanek/c/Z/10973 /prirodovedna-gramotnost-srovnavaci-analyza-2.-cast.html/

McComas, W. F. (2014). Nature of science in the science curriculum and in teacher education programs in the United States. In M. R. Matthews (Ed.), International handbook of research in history, philosophy and science teaching (s. 1993-2023). Dordrecht: Springer.

Metz, D. (2014). The history and philosophy of science in science curricula and teacher education in Canada. In M. R. Matthews (Ed.), International handbook of research in history, philosophy and science teaching (s. 2025-2043). Dordrecht: Springer.

MŠMT. (2017). Rámcový vzdělávací program pro základní vzdělávání. Praha: MŠMT. Dostupné z http: / /www.msmt.cz/file/41216

Rabušicová, M., \& Záleská, K. (2016). Metodologické otázky srovnávací pedagogiky: Podněty pro koncipování komparativních studií. Pedagogická orientace, 26(3), 346-378.

Rocard, M., Csermely, P., Jorde, D., Lenzen, D., Walberg-Henriksson, H., \& Hemmo, V. (2007). Science education now: A renewed pedagogy for the future of Europe. Luxembourg: Office for Official Publications of the European Communities. Dostupné z http://ec.europa.eu /research/science-society/document_library/pdf_06/report-rocard-on-science-education _en.pdf

Rutherford, F. J. (2001). Fostering the history of science in American science education. In F. Bevilacqua, E. Giannetto, \& M. Matthews (Eds.), Science education and culture: The contribution of history and philosophy of science (s. 41-52). Dordrecht: Kluwer Academic Publishers.

Štech, S. (2013). Když je kurikulární reforma evidence-less. Pedagogická orientace, 23(5), 615-633.

Taylor, J. L., \& Hunt, A. (2014). History and philosophy of science and the teaching of science in England. In M. R. Matthews (Ed.), International handbook of research in history, philosophy and science teaching (s. 2045-2081). Dordrecht: Springer.

VúP. (2007). Rámcový vzdělávací program pro gymnázia. Praha: VúP. Dostupné z http://www .nuv.cz/t/rvp-pro-gymnazia 
Wang, H., \& Schmidt, W. (2001). History, philosophy and sociology of science in science education: Results from the third international mathematics and science study. In F. Bevilacqua, E. Giannetto, \& M. Matthews (Eds.), Science education and culture: The contribution of history and philosophy of science (s. 83-102). Dordrecht: Kluwer Academic Publishers.

Mgr. Jana Poupová, Ph.D., katedra učitelství a didaktiky biologie Př́rodovědecká fakulta, Univerzita Karlova Viničná 7, 12800 Praha jana.poupova@natur.cuni.cz 
18 